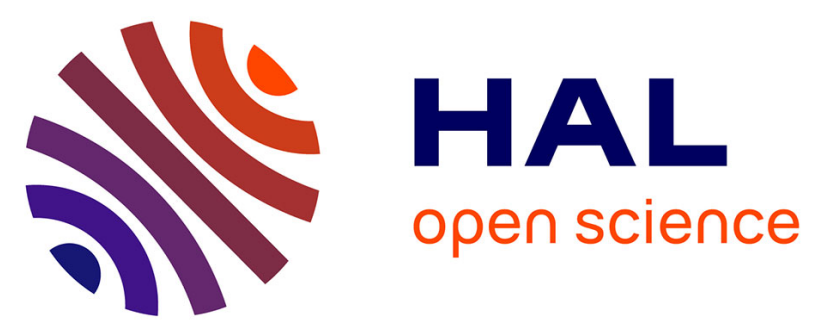

\title{
Contrasting spatiotemporal patterns and environmental drivers of diversity and community structure of ammonia oxidizers, denitrifiers, and anammox bacteria in sediments of estuarine tidal flats
}

\author{
Anjing Yang, Xiaoli Zhang, Hélène Agogué, Christine Dupuy, Jun Gong
}

\section{To cite this version:}

Anjing Yang, Xiaoli Zhang, Hélène Agogué, Christine Dupuy, Jun Gong. Contrasting spatiotemporal patterns and environmental drivers of diversity and community structure of ammonia oxidizers, denitrifiers, and anammox bacteria in sediments of estuarine tidal flats. Annals of Microbiology, 2015, 65 (879-890), http://link.springer.com/journal/13213. 10.1007/s13213-014-0929-5 . hal-01086914

\author{
HAL Id: hal-01086914 \\ https://hal.science/hal-01086914
}

Submitted on 25 Nov 2014

HAL is a multi-disciplinary open access archive for the deposit and dissemination of scientific research documents, whether they are published or not. The documents may come from teaching and research institutions in France or abroad, or from public or private research centers.
L'archive ouverte pluridisciplinaire HAL, est destinée au dépôt et à la diffusion de documents scientifiques de niveau recherche, publiés ou non, émanant des établissements d'enseignement et de recherche français ou étrangers, des laboratoires publics ou privés. 
1 Contrasting spatiotemporal patterns and environmental drivers of diversity and community structure of

2 ammonia oxidizers, denitrifiers, and anammox bacteria in sediments of estuarine tidal flats

4 Anjing Yang Xiaoli Zhang Hélène Agogué Christine Dupuy Jun Gong

5

6 A. Yang X. Zhang* J. Gong*

7 Laboratory of Environmental Microbiology, Key Laboratory of Coastal Environmental Processes, Yantai Institute of

8 Coastal Zone Research, Chinese Academy of Sciences, Yantai, China

$9 \quad *$ email: xlzhang@yic.ac.cn; jgong@yic.ac.cn

10

11 A. Yang

12 University of Chinese Academy of Sciences, Beijing, China

13

14 H. Agogué C. Dupuy

15 Littoral, Environnement et Sociétés (LIENSS) UMR 7266 CNRS - University of La Rochelle, La Rochelle, France 


\section{Abstract}

18 9

The spatial and temporal patterns of diversity, community structure, and their drivers are fundamental issues in microbial ecology. This study aimed to investigate the relative importance of spatial and seasonal controls on the distribution of nitrogen cycling microbes in sediments of estuarine tidal flats, and to test the hypothesis that metals impact the distribution of nitrogen-cycling microbes in the coastal system. Two layers of sediment samples were collected from three estuarine tidal flats of Laizhou Bay in 2010 winter and 2011 summer. The alpha diversities (Shannon and Simpson indices) and community structure of ammonia oxidizing bacteria (AOB) and archaea (AOA), denitrifier and anammox bacteria (AMB) were revealed using denaturing gradient gel electrophoresis and clone library analysis of amoA, nosZ and 16S rRNA gene markers. We found that both AOB and AMB exhibited distinct seasonal patterns in either alpha diversity or community turnover; AOA had different alpha diversities in two layers, but neither spatial nor seasonal patterns were found for their community turnover. However, no distinct spatiotemporal pattern was observed for either diversity or community composition of nosZ-type denitrifiers. For correlations between alpha diversities and environmental factors, significant correlations were found between AOB and ammonium, temperature and $\mathrm{As}$, between denitrifiers and nitrite, salinity and $\mathrm{Pb}$, and between $\mathrm{AMB}$ and $\mathrm{Pb}, \mathrm{C} / \mathrm{N}$, ammonium, $\mathrm{pH}$ and $\mathrm{DO}$. Salinity and sediment grain size were the most important factors shaping AOB and AOA communities, respectively; whereas AMB community structure was mostly determined by temperature, dissolved oxygen, $\mathrm{pH}$ and heavy metals As and Cd. These results stress that ammonia oxidizers, denitrifiers and anammox bacteria have generally different distributional patterns across time and space, and heavy metals might have contributed to their differentiated distributions in coastal sediments.

Keywords Biogeography Community turnover Environmental factors Heavy metals Nitrogen cycle 


\section{Introduction}

Microbe-driven nitrification, denitrification, and the anaerobic ammonium oxidation (anammox) play a pivotal role in nitrogen cycling in estuarine and coastal systems (Spencer and MacLeod 2002; Howarth and Marino 2006; Lam et al. 2007). These processes can relieve nitrogen load delivered to coastal waters, reducing the risk of eutrophication (Howarth 2008).

The spatial and temporal patterns of the diversity and distribution of N-cycling functional groups underlie the changes of $\mathrm{N}$-cycling processes. Based on the amoA gene (encoding ammonia monooxygenase), Ammonia oxidation was previously thought to be restricted to ammonia-oxidizing bacteria (AOB), whichare mostly presented by the $\beta$-proteobacterial Nitrosomonas and Nitrosospira, and a few in the $\gamma$-proteobacterial Nitrosococcus (Purkhold et al. 2000; Horz et al. 2004). Dang et al. (2010b) reported that nearby wastewater treatment plants and polluted rivers could have significant impact on AOB composition and distribution of Jiaozhou Bay estuary. Afterwards, ammonia-oxidizing archaea (AOA) belonging to the Crenarchaeota Group 1.1a and Group 1.1b (now known as a separate clade, Thaumarchaeota, Brochier-Armanet et al. 2008) were revealed to be critical for the global nitrogen cycle, which also had functional amoA gene (Francis et al. 2007; Zhang et al. 2012). Francis et al. (2005) observed that AOA were pervasive in marine water columns and sediments, and diverse and distinct AOA communities were associated with each of these habitats. The nos $Z$ gene codes for nitrous oxide reductase which catalyzes the reduction of $\mathrm{N}_{2} \mathrm{O}$ to $\mathrm{N}_{2}$, the final step of denitrification. Scala and Kerkhof (1999) investigated the diversity of nosZ gene in sediments obtained from the Atlantic Ocean and Pacific Ocean continental shelves and found that denitrifier communities might be restricted geographically. Like denitrification, anammox contributed significantly to the production of $\mathrm{N}_{2}$. The anammox bacterial specific 16S rRNA (AMB 16S rRNA) gene in Mai Po estuary sediment performed strong seasonal dynamics due to the anthropogenic and terrestrial inputs ( $\mathrm{Li}$ et al. 2011).

Salinity has been reported as the most important driver for ammonia oxidizer communities. The shift from low-salinity Nitrosomonas communities to high-salinity Nitrosospira communities has been observed in many estuarine systems (Francis et al. 2003; Bernhard et al. 2005; Jin et al. 2011). AOA amoA sequences often formed distinct groups according to salinity (Moister and Francis 2008; Abell et al. 2010). Additionally, AOA were proposed to be important actors in low-nutrient, low-pH, and sulfide-containing environments (Erguder et al. 2009). There were spatial and temporal variations of denitrifying communities at the Fitzroy River and San Francisco Bay estuaries, and salinity, organic carbon, nitrogen, chlorophyll- $\alpha$ and some metals were found to be factors influencing the community structure (Abell et al. 2010; Moister and Francis 2010). The anammox bacterial distributions presented strong spatial and 
seasonal variations along the Cape Fear River estuarine gradient, which were also highly correlated with salinity variation (Dale et al. 2009). Nevertheless, our knowledge about spatiotemporal patterns and controls of N-cycling microbial communities in tidal flats with high anthropogenic disturbance is limited. The dynamics of these nitrogen-removal groups are likely to be complex and tightly coupled when they compete for a common ecological niche. However, studies examining and comparing the seasonal and spatial patterns of ammonia oxidizers, denitrifiers, and anammox bacteria in a single survey are still rare.

Estuarine sediments are also sinks of metals from different origins. Trace amounts of some metals, which are necessary cofactors in enzymes or co-enzymes and electron transport chains, can be stimulatory to microbial activity (Granger and Ward 2003, Yang et al. 2013). There are evidences that metals may be an important factor in regulating nitrogen transformations in sediment habitats. For example, in the Douro River estuary (north-west Portugal), the transcription diversity of nos $Z$ gene showed a drastic decrease with the increase of Cu concentration (Magalhães et al. 2011). The metal toxicity was modulated by sediment properties (metal concentrations, grain size, organic carbon to nitrogen ratio, etc.), and denitrification revealed high sensitivity to heavy metals $\mathrm{Cu}, \mathrm{Cr}, \mathrm{Pb}, \mathrm{Zn}$ and $\mathrm{Cd}$ in sandy sites but not in muddy sites (Magalhães et al. 2007). However, the effect of heavy metals on nitrogen cycling populations in sediments has not been studied sufficiently, and little is known about the linkage between metals and the nitrogen microbial community structure in estuarine systems.

Estuarine tidal flats of the Laizhou Bay (LZB), a semi-enclosed bay of the Bohai Sea, northern China, have been hypernutrified due to high level of dissolved inorganic nitrogen (DIN), organic pollutants and heavy metals discharged from coastal industries (e.g. aquaculture, subsurface brine industries and dyeing industries) and agriculture (Hu et al. 2010; Zhang et al. 2014). These tidal flats thus present ideal environments for studying the multiple environmental stresses on nitrogen-removal microorganisms. We have carried out an ecological study on benthic microbial nitrogen cycling in this area, and demonstrated that abundances of $\mathrm{N}$-cycling functional groups respond differently to variations of environmental conditions, and metals $\mathrm{Cu}$ and $\mathrm{Cd}$ affect AOA/AOB dominance (Zhang et al. 2014). As another contribution, this study focused on the following objectives: (1) to investigate the relative importance of spatial (locations, layers) and seasonal controls on the distribution of ammonia oxidizers, denitrifiers, and anammox bacteria, and (2) to test the hypothesis that metals impact the diversity and community composition of nitrogen microbial community in the estuarine system.

\section{Materials and Methods}


Sampling and environmental parameters analysis

The physical conditions of three hypernutrified estuarine tidal flats in mouths of Jiaolai River (JL), Bailang River (BL) and Di River (Di) of the Laizhou Bay has been described previously in detail (Zhang et al. 2014). These three rivers have different pollution history and discharge sources (e.g. dying industries, mariculture and brine industries). The sampling and analysis of the environmental parameters including dissolved oxygen, $\mathrm{pH}$, salinity, and temperature of overlying water, and nitrate, nitrite, ammonium, total organic carbon and nitrogen contents, sediment grain size, and trace metal As, $\mathrm{Co}, \mathrm{Cd}, \mathrm{Cr}, \mathrm{Cu}, \mathrm{Ni}, \mathrm{Pb}, \mathrm{Zn}$ levels of sediments, were also performed as described in the previous publication (Zhang et al. 2014).

In brief, surface sediment samples were collected in 2010 winter (November) and 2011 summer (August), and three sediment replicates (JL1-3, BL1-3 and Di1-3) were randomly sampled in each estuarine tidal flat. The sediment cores were sectioned into the upper layer $(0-2 \mathrm{~cm})$ and the lower layer $(2-5 \mathrm{~cm})$. The sediment samples were referred to as the location, layer and season collected (e.g. JL-U-W and JL-L-W).

DNA extraction and PCR amplification

The environmental genomic DNA was extracted from $0.5 \mathrm{~g}$ of sediment using the Ultra Clean Soil DNA Isolation kit (Mo-Bio, USA). DNA concentration was quantified using a NanoDrop 2000C Spectrophotometer (Thermo Scientific, USA). The DNA was diluted 10 times before the PCR amplification.

PCR primers used in this study were shown in Table 1. The PCR amplification procedure was performed with a Tprofessional Thermocycler (Biometra, Germany) using the PCR kit DreamTaq ${ }^{\mathrm{TM}}$ Green PCR Master Mix (Fermentas, USA). The reactions were set up in volumes of $25 \mu \mathrm{l}$ containing $1 \mu \mathrm{l}$ template DNA, $400 \mathrm{nM}$ of each primer, and $12 \mu \mathrm{l}$ of PCR Master Mix. PCR programs were as follows: $95^{\circ} \mathrm{C}$ for $3 \mathrm{~min}, 30-35$ cycles of $95^{\circ} \mathrm{C}$ for $30 \mathrm{~s}, 57^{\circ} \mathrm{C}$ (amoA1F/amoA-rnew) or $\quad 56^{\circ} \mathrm{C} \quad$ (Arch-amoAF/Arch-amoAR) or $\quad 53^{\circ} \mathrm{C} \quad$ (nosZF/nosZ1622R) $\quad$ or $58^{\circ} \mathrm{C}$ (Pla46f-GC/Amx368r) for $40 \mathrm{~s}$, followed by $72^{\circ} \mathrm{C}$ for $40 \mathrm{~s}$, and finally $72^{\circ} \mathrm{C}$ for $10 \mathrm{~min}$.

Denaturing gradient gel electrophoresis, cloning and sequencing

PCR products of AMB $16 \mathrm{~S}$ rRNA gene were analyzed by denaturing gradient gel electrophoresis (DGGE) with a DCode mutation detection system (Bio-Rad, USA). Forty $\mu$ l PCR products $(100-200 \mathrm{ng} / \mu \mathrm{l})$ were loaded onto a $6 \%$ 
polyacrylamide gel with a denaturant gradient between $20 \%$ and $80 \%$ (100\% denaturant containing $7 \mathrm{M}$ urea and $40 \%$ formamide). Electrophoreses were run at a constant voltage of $200 \mathrm{~V}$ and $60^{\circ} \mathrm{C}$ for $5 \mathrm{~h}$. Subsequently, the gels were stained for $30 \mathrm{~min}$ in $1 \times$ GeneFinder (Bio-V, China), and then visualized in an imaging system (Syngene, USA). The main bands were excised and incubated overnight at $4{ }^{\circ} \mathrm{C}$ in $30 \mu \mathrm{l}$ sterilized deionized water as templates for reamplification. The PCR products were checked for single bands on DGGE, purified using a Purification Kit (Tiangen Biotech, China), and sequenced by a commercial company (Sangon, Shanghai, China). DGGE images were analyzed using Quantity One 2.1 (Bio-Rad, USA) to generate a densitometric profile. The peak areas of the fingerprint patterns were used to indicate the intensities. Bands with a relative intensity of less than $0.5 \%$ of the sum of all band intensities were discarded.

As for AOB amoA, AOA amoA and nosZ genes, triplicate of PCR products were pooled, ligated into the pTZ57R/T vector (Fermentas), and transferred into competent Escherichia coli TOP10 cells (Tiangen). Therefore, 12 clone libraries of each gene were constructed for 3 sampling locations, 2 layers and 2 seasons. Positive recombinants were selected using X-Gal-IPTG LB indicator plates amended with ampicillin $(100 \mathrm{mg} / \mathrm{ml})$. The insertion was determined by PCR amplification with the universal primer set M13F and M13R. Amplicons of correct size were digested separately with endonucleases (Fermentas) HhaI, RsaI for amoA gene (Jin et al. 2010), and MspI, RsaI for nosZ gene (Rich et al. 2003). Restriction fragments were resolved by electrophoresis on $2.5 \%$ agarose gels. Each restriction fragment length polymorphism (RFLP) pattern was defined as an operational taxonomic unit (OTU), and representative clones were randomly selected for sequencing (Sangon).

Alpha diversities (local diversities of a given community), such as Shannon $(H)$ and Simpson $(D)$ indices, were calculated based on number and intensities of DGGE bands, or number and relative abundance of OTUs in libraries. These indices were calculated with an online diversity calculator (http://www.changbioscience.com). The coverage $(C)$ of clone libraries was calculated as $C=[1-(\mathrm{n} 1 / \mathrm{N})] \times 100$, where $\mathrm{n} 1$ is the number of unique (frequency=1) RFLP pattern detected in a library and $\mathrm{N}$ is the total number of clones in the same library (Mullins et al. 1995).

Phylogenetic analysis and sequence deposition

Possible chimerical DNA sequences were checked with programs CHIMERA_CHECK (Gontcharova et al. 2010) and Bellerophon (Huber et al. 2004). Nucleotide sequences were aligned with GenBank sequences using ClustalW (Thompson et al. 1994). Phylogenetic trees were constructed with MEGA 5.0 (Tamura et al. 2011) using the neighbor-joining and method, and bootstrap resampling analysis for 1,000 replicates was performed to estimate the 
confidence of the tree topologies.

The nucleotide sequences obtained in this study have been deposited in the GenBank database under accession numbers JX465173 to JX465197 (AMB 16S rRNA), JX465198 to JX465201 (AOA amoA), JX465202 to JX465230 (AOB amoA), and JX465231 to JX465276 (nosZ).

Statistical analyses

Mean values of alpha diversities were compared with the pairwise $t$-test or one-way ANOVA analysis following by a least significance difference (LSD) test at the 0.05 confidence level. Spearman's correlation coefficient $(\rho)$ was calculated to explore the relationship between alpha diversities and environmental variables. These analyses were performed using the statistic software SPSS 13.0 for windows (SPSS, Chicago, USA).

Community clustering of nitrogen functional groups was analyzed with the principal coordinate analysis (PCoA) using the UniFrac program (Lozupone and Knight 2005), according to the instructions at the UniFrac website (http://bmf2.colorado.edu/unifrac/index.psp). Differences in community composition clustered by sampling location, layer and season, were pairwise or globally tested based on weighted UniFrac metric. Relationships between microbiota and environmental factors were analyzed using the software CANOCO (version 4.5, Microcomputer Power, Ithaca, USA) (Ter-Braak and Smilauer 2002). A detrended correspondence analysis (DCA) was conducted in order to decide whether a canonical correspondence analysis (CCA) or redundancy analysis (RDA) should be used in ordination (Ysebaert and Herman 2002). The statistical significance of the variable added was tested using a Monte Carlo permutation test (999 permutations).

\section{Results}

DGGE and clone library analyses

A total of 321 bands were detected in DGGE gels of AMB 16S rRNA (Fig. S1). The bands from triplicate samples were combined for subsequent analyses, and then the number of bands per sample varied between 7 and 16 (Table S1). Of 12 amoA genes of AOB and AOA, and nosZ gene clone libraries, 375, 394 and 380 insert-positive clones were identified, resulting in 29, 4 and 46 unique OTUs, respectively. The numbers of OTUs ranged from 2 to 9 (for AOB), from 2 to 4 (for AOA), and from 4 to 10 (for nosZ) (Table S1). The coverage $(C)$ values of bacterial and archaeal amoA and nosZ 
gene libraries were more than $80 \%$, indicating that most ammonia oxidizer and denitrifier had been detected. Archaeal amoA gene exhibited relatively lower diversities $(H 0.10 \sim 0.60 ; D 0.08 \sim 0.28)$, while AMB $16 \mathrm{~S}$ rRNA genes appeared highly diverse $(H 1.86 \sim 2.68 ; D 0.83 \sim 0.93)$ (Table S1).

Spatial and seasonal patterns of alpha diversities

ANOVA and t-test analyses were performed to compare the alpha diversity indices of ammonia oxidizers, denitrifiers and anammox bacteria from different sampling locations (JL, BL and Di), layers (upper and lower) and seasons (winter and summer) (Table 2). The results showed that the alpha diversities of AMB varied greatly among sampling locations, layers, or seasons, with significantly lower indices in Di tidal flat (vs. JL and BL) ( $P=0.004$ for $H ; P=0.001$ for $D$ ), in upper layer (vs. lower) ( $P=0.003$ for $H ; P=0.018$ for $D$ ) and in winter (vs. summer) ( $P=0.015$ for $H ; P=0.022$ for $D$ ). Alpha diversities of $\mathrm{AOB}$ amoA gene were significantly higher in winter than in summer ( $P=0.025$ for $H ; P=0.048$ for $D)$. Nevertheless, AOA amoA gene was more diverse in the lower than in the upper layer in terms of $D$ index $(P=0.043)$, but not in $H(P=0.068)$. No differences were found for alpha diversities of $n o s Z$ gene.

Correlations between alpha diversities and environmental factors

In order to explore the relationship between gene diversities and environmental variables, Spearman's correlations were performed (Table 3). Among the eight metals determined, six ( $\mathrm{Co}, \mathrm{Cr}, \mathrm{Cu}, \mathrm{Ni}, \mathrm{Pb}$ and $\mathrm{Zn}$ ) were collinear $(\rho>0.64$, $P<0.05$ ), and thus only $\mathrm{Pb}, \mathrm{As}$ and $\mathrm{Cd}$ was retained for subsequent correlation analyses. $H$ and $D$ of bacterial amoA were negatively correlated with the concentration of $\mathrm{NH}_{4}{ }^{+}-\mathrm{N}(\rho=-0.76$ and $-0.72, P<0.01$, respectively), temperature $(\rho=-0.69$, $P<0.05 ; \rho=-0.72, P<0.01$, respectively) and metal As $(\rho=-0.61, P<0.05)$, whereas $H$ and $D$ of archaeal amoA exhibited no correlation with all environmental variables examined. NosZ gene diversities had positive correlations with concentration of $\mathrm{NO}_{2}-\mathrm{N}(\rho=0.60, P<0.05$ for $H)$ and salinity $(\rho=0.69, P<0.05$ for $H)$, and negative correlations with $\mathrm{Pb}$ ( $\rho=-0.64$ and $-0.68, P<0.05$, for $H$ and $D$, respectively). $H$ and $D$ of AMB $16 \mathrm{~S}$ rRNA genes were positively correlated with $\mathrm{Pb}(\rho=0.74$ and $0.76, P<0.01)$, ratio of organic carbon to nitrogen $(\mathrm{C} / \mathrm{N}, \rho=0.73$ and $0.72, P<0.01$, respectively) and $\mathrm{NH}_{4}{ }^{+} \mathrm{N}(\rho=0.70$ and $0.71, P<0.05$, respectively), but negatively with $\mathrm{pH}$ of overlying water $(\rho=-0.72$ and $-0.75, P<0.01$, respectively) and DO $(\rho=-0.59, P<0.05)$.

Phylogenetic analyses 
The phylogenetic tree based on partial AOB amoA gene sequences revealed that no OTUs were common across all samples (Fig. S2). BLASTing against GenBank revealed that A large proportion (246 out of 375) of the clones closely matched with these found from hypernutrified sedimentary environments including San Francisco Bay (Mosier and Francis 2008), Pearl River (Jin et al. 2011), Jiulong River, and Jiaozhou Bay (Dang et al. 2010b), indicating anammox bacterial assemblages in these coastal environments are phylogenetically similar regardless of geographic locations. All OTUs of AOB amoA were affiliated to $\beta$-Proteobacteria and distributed into 8 clusters. Two clusters containing 120 clones appeared to be Nitrosospira-related, with the remaining clusters Nitrosomonas-related. In the Nitrosospira-related cluster, some OTUs were first detected in this study, probably representing novel Nitrosospira lineages. A Nitrosomonas-related OTU (AOB8) was closely related to sequences from Jiaozhou Bay A5 station, which was characterized by high efflux of heavy metals from wastewater treatment plant (Dang et al. 2010b).

Phylogenetic analysis of AOA amoA gene showed that a majority (364 out of 394) of sequences were placed in the “marine sediment/water" Crenarchaeota clade along with Nitrosopumilus maritimus (HM345611), a representative of Crenarchaeota group 1.1a (Fig. S3). Phylogenetically, these sequences were closely related to those from sediments of Jiaozhou Bay estuary (Dang et al. 2008), Bahia del Tobari estuary (Beman and Francis 2006) as well as wastewater treatment plants (WWTP). Only 30 clones (7.6\%) fell exclusively into the "hot spring/soil" Crenarchaeota clade, which includes the Crenarchaeota group 1.1b clone Candidatus Nitrososphaera gargensis GA15P03. Sequences between two groups exhibited only 79 80\% similarities at the nucleotide level. The most dominant OTU AOA1 (88.8\%) occurred in all clone libraries. Interestingly, OTU AOA4 was never recovered from the Di tidal flat.

All nosZ OTUs were grouped into 3 major clusters in the phylogenetic tree (Fig. S4). Cluster 1 was mainly comprised of clones closely related to $\alpha$ - and $\beta$-Proteobacteria, cluster 2 mostly to $\gamma$-Proteobacteria, and cluster 3 to $\alpha$-Proteobacteria only. There were no common genotypes across all samples and no OTUs appeared particularly dominant. More than half of nosZ sequences were affiliated with the $\alpha$-proteobacterial genera, such as Ruegeria, Nisaea, Polymorphum, Rhodobacter, Azospirillum, Mesorhizobium and Bradyrhizobium. These genera were previously found in marine sediment habitats, polluted soils, and activated sludge (Huang et al. 2001; Urios et al. 2008; Huo et al. 2011; Nie et al. 2012). The second most abundant sequences were related to $\gamma$-Proteobacteria, including genera Halomonas, Marinobacter, Pseudomonas and Alcaligenes, which were used in discoloration (Mabinya et al. 2011), heavy metals biosorption (Hussein et al. 2004) or reduction of chemical oxygen demand (COD) (Rajeshkumar and Jayachandran 2004) from high salt wastewater.

A total of 25 DGGE gel bands of AMB in different positions were excised and sequenced. All sequences grouped 
into 4 clusters in the phylogenetic tree based on the 16S rRNA genes (Fig. S5). A large proportion (15 out of 25) of our sequences was grouped into the cluster 1 , a distinct clade with $<87 \%$ sequence identity against GenBank, suggesting novel genetic diversity of AMB species in the Laizhou Bay estuaries. In cluster 2, four sequences affiliated to Candidatus Scalindua were only recovered from winter samples. None of our sequences was placed in Cluster 3, which included other well-known AMB (e.g., Kuenenia, Brocadia, Jettenia asiatica, and Anammoxoxoglobus propionicus). Cluster 4, a putative anammox or Planctomycetes cluster, contained the sequences only occurring in summer.

Spatial and seasonal patterns of community structure

According to weighted UniFrac significance tests, the community structure of AOB $(P=0.03)$ and AMB $(P<0.01)$ was seasonally different. However, the community differences in AOA or nosZ-type denitrifiers were insignificant across locations, layers or seasons $(P>0.10)$ (Table 4). These results were consistent with the PCoA plots (Fig. 1), in which $\mathrm{AOB}$ and $\mathrm{AMB}$ were evidently separated into winter and summer groups, with the first principal coordinates (P1) explaining $73.02 \%$ and $77.93 \%$ of the total community variability respectively, whereas no distinct patterns could be recognized for either AOA or denitrifiers.

Environmental factors influencing community turnover

To further understand how environmental factors impacted target gene distributions, the weighted CCA analyses were made. DCA results showed that CCA model better approximated AOB amoA and nos $Z$ species relationship to the explanatory variables (maximum gradient length greater than 4), but RDA model should be selected for AMB $16 \mathrm{~S}$ rRNA and AOA amoA (maximum gradient length less than 3). The optimal models were produced with manual deselection of collinear variables and manual forward selection via Monte Carlo permutation significance tests. Of all the environmental factors analyzed, salinity was significantly correlated with community changes of AOB $(P=0.009$; Fig. 2A). Sediment grain size was the most important factor influencing the community structure of AOA $(P=0.048)$ (Fig. 2B). The metal As had the strongest correlation with nosZ-type denitrifier community changes, though no variables were significant $(P=0.16)$ (Fig. 2C). For AMB, several environmental factors, such as temperature $(P=0.001)$, dissolved oxygen $(P=0.007), \mathrm{pH}(P=0.016)$ and metals $\mathrm{As}(P=0.029)$ and $\mathrm{Cd}(P=0.03)$, presented significant correlations (Fig. 2D); summertime samples of the Di tidal flat with high $\mathrm{pH}$ values grouped separately from these of JL and BL (Fig. 2D). 


\section{Discussion}

Sediments provide a range of niches for N-cycling microbes which could co-occur or spatiotemporally isolate. Our study investigated the alpha diversities and community structure of four functional groups, which are responsible for interlinked $\mathrm{N}$-cycling processes in sediment samples. We explored their spatial and seasonal patterns and associations with environmental conditions in estuarine tidal flats. It should be noted that the methodologies (i.e., DGGE and clone library analysis) we employed in this study may have some limitations. These include the non-intensive sampling of communities, which leads to the incapability to detect uncommon or rare phylotypes in the communities and thus underestimation of richness (Bent and Forney 2008). Nevertheless, Shannon and Simpson indices can be estimated more accurately because rare phylotypes generally have a smaller relative numerical impact, and the use of fingerprinting methods for many of samples, followed by cluster analysis or clone library analysis, are still useful in revealing distributional patterns and composition of microbial communities (Bent and Forney 2008). In this study, we found that ammonia oxidizers, denitrifiers, and anammox bacteria had contrasting distributional patterns across locations, layers or seasons, which provides an integrated view of the community assembly and underlying mechanisms

Ammonia oxidizers

Differences in ammonia oxidizers distribution in estuaries are undoubtedly determined by the complex interplay of biological and environmental variables. In this study, both ANOVA and UniFrac significance tests indicated that AOB diversity and community turnover in sediment exhibited distinct seasonal patterns (Fig. 1, Table 2). Furthermore, our correlation analysis indicated that the lower diversity of AOB in summer could be due to higher concentrations of ammonium and As in the sediment and the higher temperature (Table 3). The higher temperature will increase the activity of heterotrophic microbes in sediment, leading to the increase of remineralization which supplies more ammonium for ammonia oxidizers, of which increase of abundance should be expected. In contrast, we observed a negative correlation between AOB abundance and temperature (Zhang et al. 2014). Despite that AOB diversity was demonstrated to be higher in low-salinity sites than in high-salinity sites (Sahan and Muyzer 2008), no significant correlations between salinity and alpha diversities were found in our study. These indicate that temperature should represent a highly limited factor for AOB diversity and community size, for which differentiated ecology of AOB clades 
at different temperatures could be accounted. For instance, Sahan and Muyzer (2008) showed that Nitrosomonas spp. often was dominant in high-temperature (May, July and September) seasons, while Nitrosospira was abundant in low-temperature seasons in estuarine sediments. Tourna et al. (2008) demonstrated that in slurry incubation, Nitrosospira cluster 1 completely disappeared at high temperature $\left(30^{\circ} \mathrm{C}\right)$. Our CCA showed that salinity was the most influential physicochemical factor structuring AOB community composition (Fig. 2), which is consistent with previous studies (Francis et al. 2003; Bernhard et al. 2005; Mosier and Francis 2008; Jin et al. 2011). AOB at the high-salinity sites were most similar to Nitrosospira clade, but at the mid- and low-salinity sites were distributed among Nitrosospira and Nitrosomonas sequences (Bernhard et al. 2005). Taken together, these data suggest that alpha diversity and community composition of $\mathrm{AOB}$ in surface sediment are primarily shaped by temperature and salinity, respectively, which, in turn, account for the seasonal patterns of AOB distribution in these environments.

Our data suggest that AOA have rather stable diversity and composition in estuarine sediments, regardless of reason and location (Table 2, 4). The only significant factors we observed for Simpson index and community structure lie in the vertical distribution (upper and lower layers) and grain size of sediment (Table 2, Fig. 2). Nevertheless, although this study demonstrates clearly the distributional patterns of AOA in both diversity and composition in estuarine sediments, the underlying environmental mechanisms remain inconclusive, as the different layers and grain sizes of sediment are closely related to other environmental parameters (Andrieux-Loyer and Aminot 2001), such as dissolved oxygen and $\mathrm{pH}$, which were not measured for sediment in this study. In fact, sediment $\mathrm{pH}$ was found to be important for AOA distribution in sediments and soils (Erguder et al. 2009; Li et al. 2011).

The negative correlation between AOB diversity and metal As found in this study is coincident with our recent report that the AOB abundance was negatively correlated with As in the studied samples (Zhang et al. 2014), suggesting that $\mathrm{AOB}$ are sensitive to As, as have been demonstrated in a laboratory study that As (III and V) decreased soil potential nitrification activity and was toxic to AOB (Gong et al. 2002). The metal As is toxic to bacteria by inhibiting basic cellular functions, which are often linked with energy metabolism, microbial biomass $\mathrm{C}$ and respiration (Ghosh et al. 2004). Nevertheless, no correlation between AOA and metals was found in this study, suggesting that AOA could be more tolerant to As than AOB. In contrast, metal As contributed the most to AOA distinction in polluted mangrove sediments (Cao et al. 2011), possibly because As presented with much higher concentrations in the mangrove sediment.

\section{Denitrifiers}

Similar to AOA, nosZ-type denitrifiers exhibited neither spatial nor seasonal patterns of diversity and composition in 
this study. This is contrast to the notion that salinity is a major driver of denitrifying communities in aquatic environments on the global scale (Jones and Hallin 2010). The insignificant effect of salinity on community turnover of nosZ-type denitrifiers could be due to the fact that most of our samples were much more saline (36.3-50.3 psu) than generally expected for estuarine samples. The positive correlation between salinity and nos $Z$ gene diversity in this study remain unexplainable (Table 3), as many bacteria cannot survive in high-salinity environments, thus the high salinity should limit the bacterial diversity.

$\mathrm{Pb}$ was negatively correlated with alpha diversities of nos $\mathrm{Z}$ gene (Table 3), suggesting a potentially toxic effect of $\mathrm{Pb}$ on nosZ-type denitrifiers. The links between heavy metals and denitrifiers have been demonstrated in previous studies. For example, increase of $\mathrm{Pb}$ concentration in soils led to greater sensitivity of $\mathrm{N}_{2} \mathrm{O}$ reductase (Bollag and Barabasz 1979). $\mathrm{Pb}$ also affected the diversity of soil nirK-type denitrifiers even at the low concentration (1 ppm) (Sobolev and Begonia 2008). In San Francisco Bay estuary, $\mathrm{Pb}$ was also closely correlated with nirS-type denitrifier abundance (Moister and Francis 2010). Nevertheless, these potential effects on denitrifiers should be only attributed to $\mathrm{Pb}$, the associations with other metals $(\mathrm{Cu}, \mathrm{Co}, \mathrm{Cr}, \mathrm{Ni}$ and $\mathrm{Zn})$, which are collinear with $\mathrm{Pb}$, are also potential contributors (Cao et al. 2008).

\section{Anammox bacteria}

Comparing with other estuarine environments, such as Cape Fear River estuary (Dale et al. 2009), Mai Po Nature Reserve estuary (Li et al. 2011) and Yodo River estuary (Amano et al. 2007), the diversity of AMB in Laizhou Bay estuaries was relatively lower, as only the "Scalindua"-like phylotypes were recovered. This result is consistent with well-known adaptation of "Scalindua" to saline environments, and "Kuenenia" and "Brocadia" are low-salinity taxa (Dale et al. 2009; Junier et al. 2010). Similar to a previous study of Jiaozhou Bay estuaries (Dang et al. 2010a), this study of LZB estuaries also revealed some phylotypes which presented as putatively new clusters of AMB within the phylum Planctomycetes (Fig. S5). Despite of the lower alpha diversities, the abundance of AMB was high in the investigated sites (Zhang et al. 2014), suggesting an important role of AMB in $\mathrm{N}_{2}$ production in the sediments of LZB tidal flats.

In the high-salinity estuaries of LZB, we identified temperature and $\mathrm{pH}$ were significantly correlated with community changes of AMB (Fig. 2). High temperature environments provide special niches for some AMB, such as the presence of "Brocadia" and "Kuenenia" phylotypes in hot spring and deep-sea hydrothermal vents (Byrne et al. 2009; Jaeschke et al. 2009), and a novel "Scalindua sinooilfield" clade in high-temperature oil reservoirs (Li et al. 2010). 
$\mathrm{pH}$ can affect the equilibrium of $\mathrm{NH}_{3} / \mathrm{NH}_{4}{ }^{+}$in environments. Higher $\mathrm{pH}$ is conducive to the formation of free $\mathrm{NH}_{3}$, of which higher concentrations could inhibit anammox (Aktan et al. 2012). This explains the negative correlations of pH with diversity (Table 3), and composition of AMB (Fig. 2), and a separate AMB assemblage in the Di estuary where a large amount of alkaline water was discharged. In the meantime, our data showed that higher $\mathrm{C} / \mathrm{N}$ ratio could promote the diversity of AMB. However, Hu et al. (2012) observed higher diversity of AMB in samples with lower organic contents. The strong competition or cooperation for nitrite may occur between AMB and denitrifiers in low organic environments, leading to higher diversity of AMB (Dalsgaard and Thamdrup 2002; Rysgaard et al. 2004). In addition, heavy metals (e.g. $\mathrm{Pb}$, As and $\mathrm{Cd}$ ) also strongly influenced AMB diversity and composition in LZB sediment samples (Fig. 2, Table 3). Similarly, a significant correlation between $\mathrm{Pb}$ and hzo gene (a functional gene of AMB) diversity was revealed ( $\mathrm{Li}$ et al. 2011).

\section{Conclusions}

In summary, we investigated the spatial and seasonal patterns of alpha diversities and community turnover of co-occurring AOA, AOB, nosZ-type denitrifiers and AMB in sediment samples of LZB estuarine tidal flats. Generally speaking, these four N-cycling functional groups exhibited contrasting distribution patterns: seasonality was evident for diversities and community composition of $\mathrm{AOB}$ and $\mathrm{AMB}$, but not for $\mathrm{AOA}$ and nosZ-type denitrifiers; diversities of these N-cycling groups seldom varied with location of sampling sites or sediment layer, except for AMB which exhibited significant difference among locations and between layers. Further analyses identified different sets of physicochemical parameters that could explain the distributional patterns of these functional groups. In particular, we found that the distributions of bacterial N-cycling players (e.g., AOB, nosZ-type denitrifier and AMB) were potentially related to several heavy metals in sediments, which, however, was never found for AOA in this study. Overall, our results highlight the differentiated distributional patterns of co-occurring $\mathrm{N}$-cycling functional microbes in coastal sediments.

Acknowledgements This work was supported by the Natural Science Foundation of China (No. 41206155), the CAS Knowledge Innovation Project (No. KZCX2-YW-JC203), the CAS Scientific Innovation Program-Interdisciplinary Field, and the One Hundred Talents Program of CAS. Thanks are due to Ms. Xiaohong Guo, Beibei Xing and Dr. Kexin Zhao for helps in sampling and laboratory assistance. 


\section{References}

Abell GCJ, Revill AT, Smith C, Bissett AP, Volkman JK, Robert SS (2010) Archaeal ammonia oxidizers and nirS-type denitrifiers dominate sediment nitrifying and denitrifying populations in a subtropical macrotidal estuary. ISME J 4: $286-300$

Agogué H, Brink M, Dinasquet J, Herndl GJ (2008) Major gradients in putatively nitrifying and non-nitrifying Archaea in the deep North Atlantic. Nature 456:788-791

Aktan CK, Yapsakli K, Mertoglu B (2012) Inhibitory effects of free ammonia on Anammox bacteria. Biodegradation $23: 751-762$

Amano T, Yoshinaga I, Okada K, Yamagishi T, Ueda S, Obuchi A, Sako Y, SuwA Y (2007) Detection of anammox activity and diversity of anammox bacteria-related 16S rRNA genes in coastal marine sediment in Japan. Microbes Environ 22:232-242

Andrieux-Loyer F, Aminot A (2001) Phosphorus forms related to sediment grain size and geochemical characteristics in French coastal areas. Estuar Coast Shelf Sci 52: 617-629

Beman JM, Francis CA (2006) Diversity of ammonia-oxidizing archaea and bacteria in the sediments of a hypernutrified subtropical estuary: Bahia del Tobari, Mexico. Appl Environ Microbiol 72:7767-7777

Bent SJ, Forney LJ (2008) The tragedy of the uncommon: understanding limitations in the analysis of microbial diversity. ISME J 2:689-695

Bernhard AE, Donn T, Giblin AE, Stahl DA (2005) Loss of diversity of ammonia-oxidizing bacteria correlates with increasing salinity in an estuary system. Environ Microbiol 7:1289-1297

Boesch DF (2002) Challenges and opportunities for science in reducing nutrient over-enrichment of coastal ecosystems. Estuaries 25:744-758

Bollag JM and Barabasz W (1979) Effect of heavy metals on the denitrification process in soil. J Environ Qual 8:196-201

Brochier-Armanet C, Boussau B, Gribaldo S, Forterre P (2008) Mesophilic crenarchaeota: proposal for a third archaeal phylum, the Thaumarchaeota. Nat Rev Microbiol 6: 245-252

Byrne N, Strous M, Crepeau V, Kartal B, Birrien JL, Schmid M, Lesongeur F, Schouten S, Jaeschke A, Jetten M, Prieur D, Godfroy A (2009) Presence and a ctivity of anaerobic ammonium-oxidizing bacteria at deep-sea hydrothermal vents. ISME J 3:117-123

Cao HL, Li M, Hong YG, Gu JD (2011) Diversity and abundance of ammonia-oxidizing archaea and bacteria in polluted mangrove sediment. Syst Appl Microbiol 34:513-523 
Cao Y, Green PG, Holden PA (2008) Microbial community composition and denitrifying enzyme activities in salt marsh sediments. Appl Environ Microbiol 74:7585-7595

Dale OR, Tobias CR, Song B (2009) Biogeographical distribution of diverse anaerobic ammonium oxidizing (anammox) bacteria in Cape Fear River Estuary. Environ Microbiol 11:1194-1207

Dalsgaard T, Thamdrup B (2002) Production of $\mathrm{N}_{2}$ through anaerobic ammonium oxidation coupled to nitratereduction in marine sediments. Appl Environ Microbiol 68:1312-1318

Dang H, Chen R, Wang L, Guo L, Chen P, Tang Z, Tian F, Li S, Slotz MG (2010a) Environmental factors shape sediment anammox bacterial communities in hypernutrified Jiaozhou Bay, China. Appl Environ Microbiol 76:7036-7047

Dang H, Li J, Chen R, Wang L, Guo L, Zhang Z, Klotz MG (2010b) Diversity, abundance, and spatial distribution of sediment ammonia-oxidizing Betaproteobacteria in response to environmental gradients and coastal eutrophication in Jiaozhou Bay, China. Appl Environ Microbiol 76:4691-4702

Dang H, Zhang X, Sun J, Li T, Zhang Z, Yang G (2008) Diversity and spatial distribution of sediment ammonia-oxidizing crenarchaeota in response to estuarine and environmental gradients in the Changjiang Estuary and East China Sea. Microbiology 154:2084-2095

Erguder TH, Boon N, Wittebolle L, Marzorati M, Verstraete W (2009) Environmental factors shaping the ecological niches of ammonia-oxidizing archaea. FEMS Microbiol Rev 33: 855-869

Francis CA, Beman JM, Kuypers MM (2007) New processes and players in the nitrogen cycle: the microbial ecology of anaerobic and archaeal ammonia oxidation. ISME J 1:19-27

Francis CA, O'mullan GD, Ward BB (2003) Diversity of ammonia monooxygenase (amoA) genes across environmental gradients in Chesapeake Bay sediments. Geobiology 1:129-140

Francis CA, Roberts KJ, Beman JM, Santoro AE, Oakley BB (2005) Ubiquity and diversity of ammonia-oxidizing archaea in water columns and sediments of the ocean. Proc Natl Acad Sci USA 102: 14683-14688

Ghosh AK, Bhattacharyya P, Palb R (2004) Effect of arsenic contamination on microbial biomass and its activities in arsenic contaminated soils of Gangetic West Bengal, India. Environ Int 30: 491-499

Gong P, Siciliano SD, Sriastava S, Greer CW, Sunaharal GI (2002) Assessment of pollution-induced microbial community tolerance to heavy metals in soil using ammonia-oxidizing bacteria and biolog assay. Hum Ecol Risk Assess 8:1067-1081

Gontcharova V, Youn E, Wolcott RD, Hollister EB, Gentry TJ, Dowd SE (2010) Black box chimera check (B2C2): a windows-based software for batch depletion of chimeras from bacterial 16S rRNA gene datasets. Open Microbiol J 
4: $47-52$

Granger J, Ward BB (2003) Accumulation of nitrogen oxides in copper-limited cultures of denitrifying bacteria. Limnol Oceanogr 48: $313-318$

Horz H, Barbrook A, Field CB, Bohannan BJM (2004) Ammonia-oxidizing bacteria respond to multifactorial global change. PNAS 101:15136-15141

Howarth RW (2008) Coastal nitrogen pollution: a review of sources and trends globally and regionally. Harmful Algae 8:14-20

Howarth RW, Marino R (2006) Nitrogen as the limiting nutrient for eutrophication in coastal marine ecosystems: evolving views over three decades. Limnol Oceanogr 51:364-376

Huang JS, Wu CS, Jin CG, Chen CT (2001) Effect of addition of Rhodobacter sp. to activiated-sludge reactors treating piggery wastewater. Wat Res 35:3867-3875

Huber T, Faulkner G, Hugenholtz P (2004) Bellerophon: a program to detect chimeric sequences in multiple sequence alignments. Bioinformatics 20:2317-2319

Huo YY, Xu XW, Li X, Liu C, Cui HL, Wang CS, Wu M (2011) Ruegeria marina sp. nov., isolated from marine sediment. Int J Syst Evol Microbiol 61:347-350

Hussein H, Hussein SF, Kandee K, Moawad H (2004) Biosorption of heavy metals from waste water using Pseudomonas sp. Electron J Biotechn 7:30-37

Hu NJ, Shi XF, Huang P, Liu JH (2010) Polycyclic aromatic hydrocarbons in surface sediments of Laizhou Bay, Bohai Sea, China. Environ Earth Sci 63:121-133

Hu B, Shen L, Zheng P, Hu A, Chen T, Cai C, Liu S, Lou L (2012) Distribution and diversity of anaerobic ammonium-oxidizing bacteria in the sediments of the Qiantang River. Environ Microbiol Rep 4: 540-547

Jaeschke A, den Camp HJMO, Harhangi H, Klimiuk A, Hopmans EC, Jetten MSM, Schouten S, Damste JSS (2009) 16S rRNA gene and lipid biomarker evidence for anaerobic ammonium-oxidizing bacteria (anammox) in California and Nevada hot springs. FEMS Microbiol Ecol 67:343-350

Jin T, Zhang T, Ye L, Lee OO, Wong YH, Qian PY (2011) Diversity and quantity of ammonia-oxidizing archaea and bacteria in sediment of the Pearl River Estuary, China. Appl Microbiol Biotechnol 90: 1137-1145

Jin T, Zhang T, Yan QM (2010) Characterization and quantification of ammonia-oxidizing archaea (AOA) and bacteria (AOB) in a nitrogen-removing reactor using T-RFLP and qPCR. Appl Microbiol Biotechnol 87: 1167-1176

Jones CM, Hallin S (2010) Ecological and evolutionary factors underlying global and local assembly of denitrifier communities. ISME J 4:633-641 
Junier P, Molina V, Dorador C, Hadas O, Kim OS, Junier T, Witzel KP, Imhoff JF (2010) Phylogenetic and functional marker genes to study ammonia-oxidizing microorganisms (AOM) in the environment. Appl Environ Microbiol $85: 425-440$

Lam P, Jensen MM, Lavik G, McGinnis DF, Muller B, Schubert CJ, Amann R, Thamdrup B, Kuypers MM (2007) Linking crenarchaeal and bacterial nitrification to anammox in the Black Sea. Proc Natl Acad Sci USA 104: 7104-7109

Li H, Chen S, Mu BZ, Gu JD (2010) Molecular detection of anaerobic ammonium-oxidizing (anammox) bacteria in high-temperature petroleum reservoirs. Microb Ecol 60:771-783

Li M, Cao H, Hong YG, Gu JD (2011) Seasonal dynamics of anammox bacteria in estuarial sediment of the Mai Po Nature Reserve revealed by analyzing the 16S rRNA and hydrazine oxidoreductase ( $h z o$ ) genes. Microbes Environ $26: 5-22$

Lozupone C, Knight R (2005) UniFrac: a new phylogenetic method for comparing microbial communities. Appl Environ Microbiol 71: 8228-8235

Mabinya LV, Cosa S, Mkwetshana N, Okoh AI (2011) Halomonas sp. OKOH-a marine bacterium isolated from the bottom sediment of Algoa Bay-produces a polysaccharide bioflocculant: partial characterization and biochemical analysis of its properties. Molecules 16:4358-4370

Magalhães C, Costa J, Teixeira C, Bordalo AA (2007) Impact of trace metals on denitrification in estuarine sediments of the Douro River estuary, Portugal. Mar Chem 107:332-341

Magalhães CM, Machado A, Matos P, Bordalo AA (2011) Impact of copper on the diversity, abundance and transcription of nitrite and nitrous oxide reductase genes in an urban European estuary. FEMS Microbiol Ecol $77: 274-284$

Mosier AC, Francis CA (2008) Relative abundance and diversity of ammonia-oxidizing archaea and bacteria in the San Francisco Bay estuary. Environ Microbiol 10:3002-3016

Mosier AC, Francis CA (2010) Denitrifier abundance and activity across the San Francisco Bay estuary. Environ Microbiol Rep 2: 667-676

Mullins TD, Britschgi TB, Krest RL, Giovannoni SJ (1995) Genetic comparisons reveal the same unknown bacterial lineages in Atlantic and Pacific bacterioplankton communities. Limnol Oceanogr 40:148-158

Najjar RG, Walker HA, Anderson PJ, Barron EJ, Bord RJ, Gibson JR, Kennedy VS, Knight CG, Megonigal JP, O’Connor RE, Polsky CD, Psuty NP, Richards BA, Soreson LG, Steele EM, Swanson RS (2000) The potential impacts of climate change on the mid-Atlantic coastal region. Climatic Res 14:219-233 
Nie Y, Tang YQ, Chi CQ, Cai M, Wu XL (2012) The genome sequence of Polymorphum gilvum SL003B-26A1 ${ }^{\mathrm{T}}$ reveals $^{2}$ its genetic basis for crude oil degradation and adaptation to the saline soil. PLoS ONE 7:e31261

Purkhold U, Pommerening-Roser A, Juretschko S, Schmid MC, Koops H, Wagner M (2000) Phylogeny of all recognized species of ammonia oxidizers based on comparative $16 \mathrm{~S}$ rRNA and amoA sequence analysis: implications for molecular diversity surveys. Appl Environ Microbiol 66:5368-5382

Rajeshkumar K, Jayachandran K (2004) Treatment of dairy wastewater using a selected bacterial isolate, Alcaligenes sp. MMRR7. Appl Biochem Biotechnol 118:65-72

Rich JJ, Heichen RS, Bottomley PJ, Cromack Jr K, Myrold DD (2003) Community composition and functioning of denitrifying bacteria from adjacent meadow and forest soils. Appl Environ Microbiol 69:5947-5982

Rysgaard S, Glud RN, Risgaard-Petersen N, Dals-gaard T (2004) Denitrification and anammox activity in Arctic marine sediments. Limnol Oceanogr 49:1493-1502

Sahan E, Muyzer G (2008) Diversity and spatio-temporal distribution of ammonia oxidizing archaea and bacteria in sediments of the Westerschelde estuary. FEMS Microbiol Ecol 64:175-186

Sanchez-Melsio A, Caliz J, Balaguer MD, Colprim J, Vila X (2009) Development of batch-culture enrichment coupled to molecular detection for screening of natural and man-made environments in search of anammox bacteria for N-removal bioreactors systems. Chemosphere 75:169-179

Scala DJ and Kerkhof (1999) Diversity of nitrous oxide reductase (nosZ) genes in continental shelf sediments. Appl Environ Microbiol 65:1681-1687

Sobolev D and Begonia MFT (2008) Effects of heavy metal contamination upon soil microbes: lead-induced changes in general and denitrifying microbial communities as evidenced by molecular markers. Int J Environ Res Pub Heal $5: 450-456$

Spencer KL, MacLeod CL (2002) Distribution and partitioning of heavy metals in estuarine sediment cores and implications for the use of sediment quality standards. Hydrol Earth Syst Sci 6:989-998

Tamura K, Peterson D, Peterson N, Stecher G, Nei M, Kumar S (2011) MEGA5: Molecular evolutionary genetics analysis using maximum likelihood, evolutionary distance, and maximum parsimony ethods. Mol Biol Evol 28:2731-2739

Ter-Braak CJF, Smilauer P (2002) CANOCO reference manual and CanoDraw for windows user's guide: software for canonical ordination (version 4.5). Ithaca NY, USA: Microcomputer Power

Thompson JD, Higgins DG, Gibson TJ (1994) Clustal W: improving the sensitivity of progressive multiple sequence alignment through sequencing weighting, position sequence gap penalties and weight matrix choice. Nucleic Acids 
Tourna M, Freitag TE, Nicol GW, Prosser JI (2008) Growth, activity and temperature responses of ammonia-oxidizing archaea and bacteria in soil microcosms. Environ Microbiol 10:1357-1364

Urios L, Michotey V, Intertaglia L, Intertaglia F, Lebaron P (2008) Nisaea denitrificans gen. nov., sp. nov. and Nisaea nitritireducens sp. nov., two novel members of the class Alphaproteobacteria from the mediterranean sea. Int $\mathbf{J}$ Syst Evol Microbiol 58: 2336-2341

Yang GF, Ni WM, Wu K, Wang H, Yang BE, Jia XY, Jin RC (2013) The effect of Cu(II) stress on the activity, performance and recovery on the anaerobic ammonium-oxidizing (Anammox) process. Chem Eng J 226: 39-45

Ysebaert T, Herman PMJ (2002) Spatial and temporal variation in benthic macrofauna and relationships with environmental variables in an estuarine, intertidal soft-sediment environment. Mar Ecol Prog Ser 244:105-124

Zhang LM, Hu HW, Shen JP, He JZ (2012) Ammonia-oxidizing archaea have more important role than ammonia-oxidizing bacteria in ammonia oxidation of strongly acidic soils. ISME J 6:1032-1045

Zhang XL, Agogué H, Dupuy C, Gong J (2014) Relative abundance of ammonia oxidizers, denitrifiers, and anammox bacteria in sediments of hypernutrified estuarine tidal flats and in relation to environmental conditions. Clean-Soil, Air, Water. DOI: 10.1002/clen.201300013

Zhou ZF, Zheng YM, Shen JP, Zhang LM, He JZ (2011) Response of denitrification genes nirS, nirK, and nosZ to 568 
Tables

570 Table 1 Characteristics of the PCR primers used in the study

\begin{tabular}{|c|c|c|c|c|c|}
\hline Application & Target gene & Primer & Sequence $\left(5^{\prime}-3^{\prime}\right)$ & $\begin{array}{l}\text { Length of } \\
\text { amplicon (bp) }\end{array}$ & Reference \\
\hline \multirow[t]{3}{*}{ Cloning } & AOB amoA & $\begin{array}{l}\text { amoA1F } \\
\text { amoArnew }\end{array}$ & $\begin{array}{l}\text { GGGGTTTCTACTGGTGGT } \\
\text { ССССТCBGSAAAVCCTTCTTC }\end{array}$ & 490 & $\begin{array}{l}\text { Agogué et al. } \\
2008\end{array}$ \\
\hline & AOA $a m o A$ & $\begin{array}{l}\text { Arch-amoAF } \\
\text { Arch-amoAR }\end{array}$ & $\begin{array}{l}\text { STAATGGTCTGGCTTAGACG } \\
\text { GCGGCCATCCATCTGTATGT }\end{array}$ & 635 & $\begin{array}{l}\text { Agogué et al. } \\
2008\end{array}$ \\
\hline & $n o s Z$ & $\begin{array}{l}\text { nosZ-F } \\
\text { nosZ1622R }\end{array}$ & $\begin{array}{l}\text { CGYTGTTCMTCGACAGCCAG } \\
\text { CGSACCTTSTTGCCSTYGCG }\end{array}$ & 267 & $\begin{array}{l}\text { Zhou et al. } \\
2011\end{array}$ \\
\hline
\end{tabular}

571

$\mathrm{GC}^{*}=$ CCGCCGCGCGGCGGGCGGGGCGGGGCACGGGGGG 
573 Table 2 Comparison of Shannon $(H)$ and Simpson $(D)$ diversities of target genes across sampling locations or layers or

574 seasons using the one-way ANOVA or $t$-test analyses*

\begin{tabular}{|c|c|c|c|c|c|c|c|c|}
\hline & \multicolumn{2}{|c|}{ AOB amoA } & \multicolumn{2}{|c|}{ AOA amoA } & \multicolumn{2}{|c|}{$\operatorname{nos} Z$} & \multicolumn{2}{|c|}{ AMB 16S rRNA } \\
\hline & $H$ & $D$ & $H$ & $D$ & $H$ & $D$ & $H$ & $D$ \\
\hline \multicolumn{9}{|l|}{ Location } \\
\hline $\mathrm{JL}$ & $1.14 \pm 0.17$ & $0.63 \pm 0.06$ & $0.38 \pm 0.06$ & $0.18 \pm 0.04$ & $1.31 \pm 0.26$ & $0.63 \pm 0.10$ & $2.43 \pm 0.13^{\mathrm{a}}$ & $0.9 \pm 0.01^{\mathrm{a}}$ \\
\hline BL & $1.10 \pm 0.31$ & $0.56 \pm 0.10$ & $0.31 \pm 0.10$ & $0.14 \pm 0.05$ & $1.35 \pm 0.09$ & $0.71 \pm 0.02$ & $2.48 \pm 0.06^{\mathrm{a}}$ & $0.9 \pm 0.01^{\mathrm{a}}$ \\
\hline Di & $1.21 \pm 0.23$ & $0.61 \pm 0.09$ & $0.20 \pm 0.05$ & $0.09 \pm 0.02$ & $1.65 \pm 0.18$ & $0.76 \pm 0.05$ & $1.96 \pm 0.04^{\mathrm{b}}$ & $0.84 \pm 0.00^{\mathrm{b}}$ \\
\hline$P$-value & 0.951 & 0.844 & 0.270 & 0.264 & 0.417 & 0.379 & 0.004 & 0.001 \\
\hline \multicolumn{9}{|l|}{ Layer } \\
\hline Upper & $0.99 \pm 0.16$ & $0.55 \pm 0.06$ & $0.21 \pm 0.05$ & $0.09 \pm 0.02$ & $1.43 \pm 0.11$ & $0.71 \pm 0.04$ & $2.23 \pm 0.12$ & $0.88 \pm 0.01$ \\
\hline Lower & $1.31 \pm 0.19$ & $0.64 \pm 0.06$ & $0.38 \pm 0.06$ & $0.18 \pm 0.03$ & $1.45 \pm 0.20$ & $0.69 \pm 0.07$ & $2.35 \pm 0.12$ & $0.89 \pm 0.01$ \\
\hline$P$-value & 0.194 & 0.283 & 0.068 & 0.043 & 0.901 & 0.782 & 0.003 & 0.018 \\
\hline \multicolumn{9}{|l|}{ Season } \\
\hline Winter & $1.43 \pm 0.13$ & $0.70 \pm 0.03$ & $0.29 \pm 0.05$ & $0.13 \pm 0.03$ & $1.50 \pm 0.14$ & $0.74 \pm 0.03$ & $2.17 \pm 0.10$ & $0.87 \pm 0.01$ \\
\hline Summer & $0.87 \pm 0.16$ & $0.50 \pm 0.06$ & $0.31 \pm 0.08$ & $0.14 \pm 0.04$ & $1.38 \pm 0.17$ & $0.65 \pm 0.07$ & $2.41 \pm 0.13$ & $0.90 \pm 0.01$ \\
\hline$P$-value & 0.025 & 0.048 & 0.848 & 0.845 & 0.661 & 0.344 & 0.015 & 0.022 \\
\hline
\end{tabular}

*Values are provided as mean and standard errors. Different superscript letters indicate significant pairwise difference $(P<0.05)$ in multiple comparison following ANOVA. All significant differences $(P<0.05)$ are highlighted in bold. 
578 Table 3 Spearman's correlation coefficients $(\rho)$ between environmental factors and Shannon $(H)$ and Simpson indices

$579(D)$ of target genes across seasons, locations and layers*

\begin{tabular}{|c|c|c|c|c|c|c|c|c|}
\hline & \multicolumn{2}{|c|}{ AOB $a m o A$} & \multicolumn{2}{|c|}{$\begin{array}{l}\mathrm{AOA} \\
a m o A\end{array}$} & \multicolumn{2}{|c|}{ nos $Z$} & \multicolumn{2}{|c|}{$\begin{array}{c}\text { AMB 16S } \\
\text { rRNA }\end{array}$} \\
\hline & $H$ & $D$ & $H$ & $D$ & $H$ & $D$ & $H$ & $D$ \\
\hline As & -0.61 & -0.61 & ns & ns & ns & ns & ns & ns \\
\hline $\mathrm{Cd}$ & ns & ns & ns & ns & ns & ns & ns & ns \\
\hline $\mathrm{Pb}$ & ns & ns & ns & ns & -0.64 & -0.68 & 0.74 & 0.76 \\
\hline $\mathrm{C} / \mathrm{N}$ & ns & ns & ns & ns & ns & ns & 0.73 & 0.72 \\
\hline DO & ns & ns & ns & ns & ns & ns & -0.59 & -0.59 \\
\hline Grain size & ns & ns & ns & ns & ns & ns & ns & ns \\
\hline $\mathrm{NH}_{4}^{+}-\mathrm{N}$ & -0.76 & -0.72 & ns & ns & ns & ns & 0.70 & 0.71 \\
\hline $\mathrm{NO}_{2}^{-}-\mathrm{N}$ & ns & ns & ns & $\mathrm{ns}$ & 0.60 & ns & ns & ns \\
\hline $\mathrm{NO}_{3}^{-}-\mathrm{N}$ & ns & ns & ns & $\mathrm{ns}$ & ns & ns & ns & ns \\
\hline $\mathrm{pH}$ & ns & ns & ns & $\mathrm{ns}$ & ns & ns & -0.72 & -0.75 \\
\hline Salinity & ns & ns & ns & ns & 0.69 & ns & ns & $\mathrm{ns}$ \\
\hline Temperature & -0.69 & -0.71 & $\mathrm{~ns}$ & ns & ns & ns & ns & ns \\
\hline
\end{tabular}

*Only the significant correlations $(P<0.05)$ are shown, and the highly significant correlations $(P<0.01)$ are highlighted in bold.

$* \mathrm{C} / \mathrm{N}=$ ratio of organic carbon to nitrogen; $\mathrm{DO}=$ dissolved oxygen; $\mathrm{ns}=$ not significant. 
584 Table 4 Comparisons of community composition of target genes among different sampling stations, layers or seasons 585 using weighted UniFrac significance test*

\begin{tabular}{lcccc}
\hline \multirow{2}{*}{ Group pairs } & \multicolumn{4}{c}{$P$-value } \\
\cline { 2 - 5 } & AOB amoA & AOA amoA & nosZ & AMB 16S rRNA \\
\hline Location & 0.96 & 1.00 & 0.99 & 1.00 \\
JL vs. BL & 1.00 & 1.00 & 1.00 & 1.00 \\
BL vs. Di & 1.00 & 1.00 & 1.00 & 0.45 \\
$\quad$ JL vs. Di & 0.73 & 0.78 & 0.42 & 0.99 \\
Layer & & & & \\
$\quad$ Upper vs. Lower & $\mathbf{0 . 0 3}$ & 0.96 & 0.68 & $\leq \mathbf{0 . 0 1}$ \\
Season &
\end{tabular}

586 *The significant correlations $(P<0.05)$ are highlighted in bold. 


\section{Figure Captions}

Figure 1 Plots of principal coordinate analysis based on UniFrac weighted metric of AOB-amoA (A), AOA-amoA (B), nosZ (C), and AMB-16S rRNA (D), showing spatial and/or seasonal changes in N-cycling microbial assemblages in sediments of estuarine tidal flats

592

Figure 2 Plots of canonical correspondence analysis and redundancy analysis showing the relationships between the environmental factors and N-cycling microbial communities of AOB-amoA (A), AOA-amoA (B), nosZ (C), and 595 anammox bacterial 16S rRNA genes (D)

596 
Figure 1
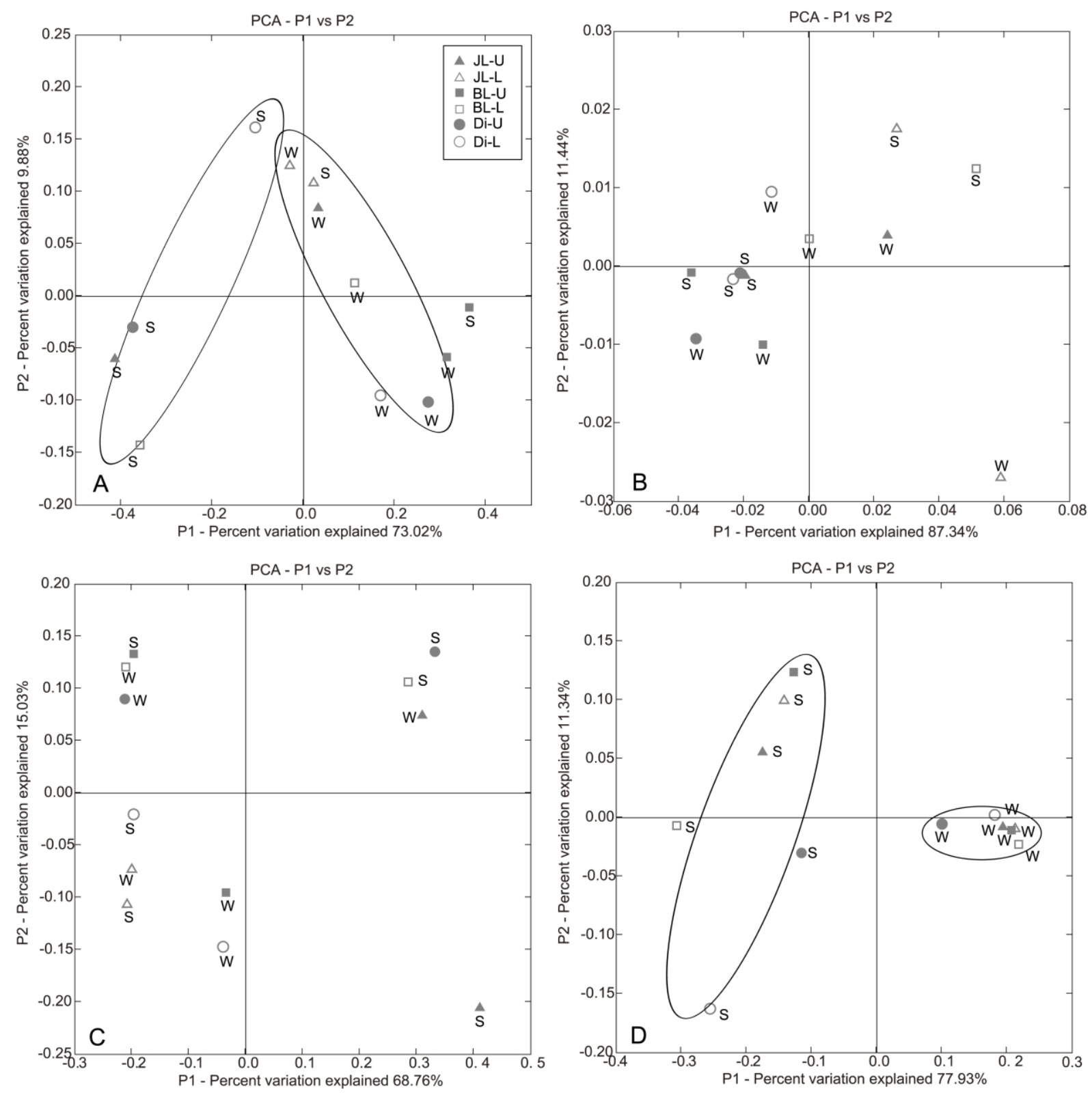

599

600

601

602 
603

604
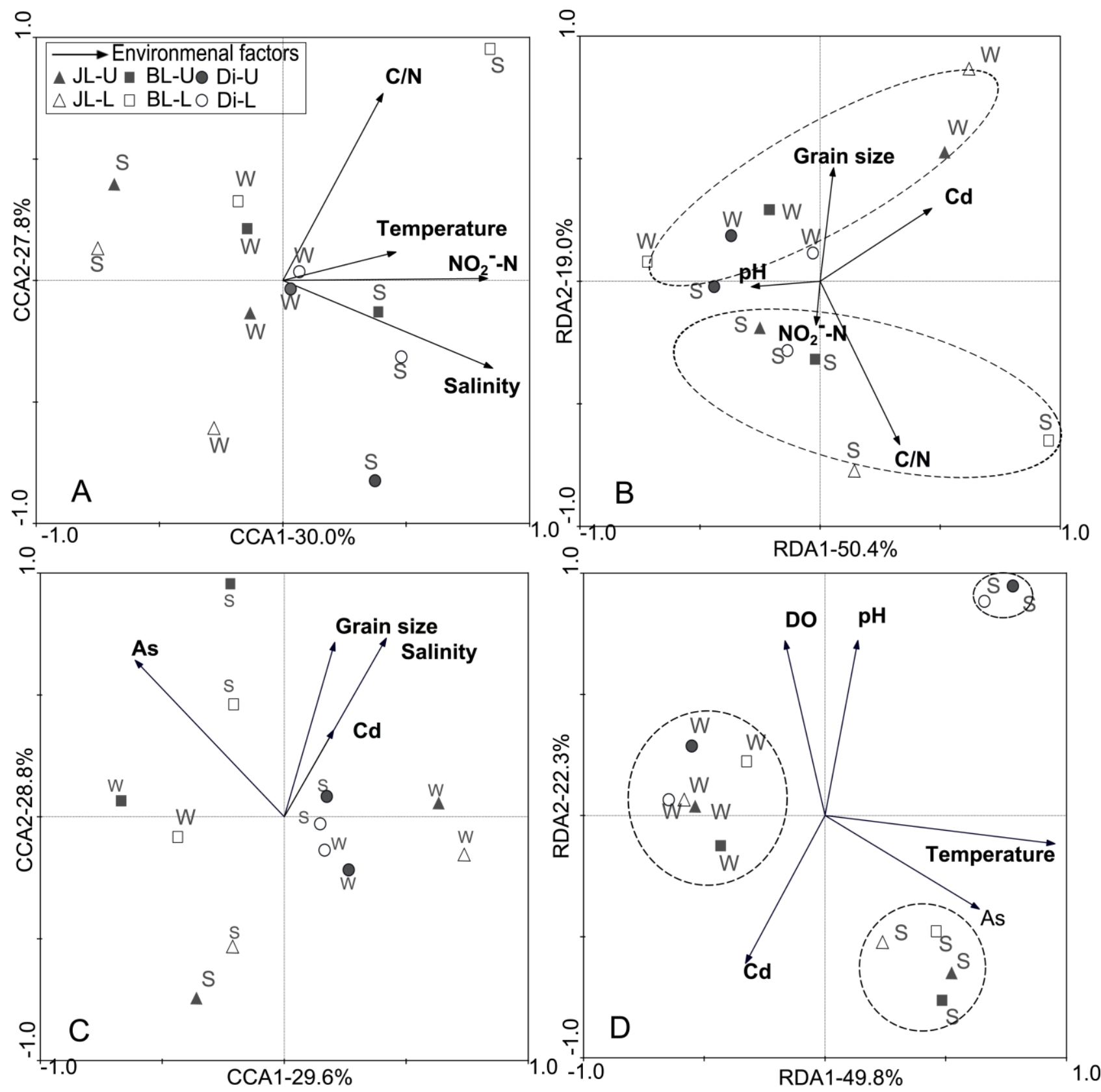
608 Table S1 Shannon $(H)$ and Simpson $(D)$ diversity and coverage $(C \%)$ estimates for AMB16S rRNA, AOB amoA, AOA amoA, and nos $Z$ genes

\begin{tabular}{|c|c|c|c|c|c|c|c|c|c|c|c|c|c|c|c|c|c|c|}
\hline \multirow{3}{*}{ Sample } & \multirow{2}{*}{\multicolumn{3}{|c|}{$\begin{array}{c}\text { DGGE } \\
\text { AMB } 16 \mathrm{~S} \text { rRNA }\end{array}$}} & \multicolumn{15}{|c|}{ Clone libraries } \\
\hline & & & & \multicolumn{5}{|c|}{$\mathrm{AOB}$ amoA } & \multicolumn{5}{|c|}{ AOA amoA } & \multicolumn{5}{|c|}{$\operatorname{nos} Z$} \\
\hline & Bands & $H$ & $D$ & $\begin{array}{l}\text { No. of } \\
\text { clones }\end{array}$ & OTUs & $C \%$ & $H$ & $D$ & $\begin{array}{l}\text { No. of } \\
\text { clones }\end{array}$ & OTUs & $C \%$ & $H$ & $D$ & $\begin{array}{l}\text { No. of } \\
\text { clones }\end{array}$ & OTUs & $C \%$ & $H$ & $D$ \\
\hline JL-U-W & 9 & 2.11 & 0.87 & 43 & 6 & 97.7 & 1.57 & 0.76 & 37 & 4 & 97.3 & 0.43 & 0.19 & 26 & 5 & 96.2 & 1.42 & 0.72 \\
\hline JL-L-W & 11 & 2.32 & 0.90 & 30 & 5 & 96.7 & 1.25 & 0.67 & 37 & 3 & 97.3 & 0.42 & 0.22 & 27 & 8 & 96.3 & 1.99 & 0.86 \\
\hline BL-U-W & 11 & 2.31 & 0.89 & 27 & 4 & 91.3 & 1.12 & 0.62 & 36 & 3 & 94.4 & 0.20 & 0.08 & 43 & 7 & 97.7 & 1.44 & 0.74 \\
\hline BL-L-W & 13 & 2.46 & 0.91 & 32 & 9 & 87.5 & 1.98 & 0.82 & 32 & 3 & 96.9 & 0.27 & 0.11 & 25 & 4 & 96.0 & 1.07 & 0.65 \\
\hline Di-U-W & 7 & 1.86 & 0.83 & 35 & 5 & 94.3 & 1.21 & 0.65 & 31 & 2 & 96.8 & 0.10 & 0.04 & 36 & 7 & 100.0 & 1.83 & 0.83 \\
\hline Di-L-W & 8 & 1.96 & 0.85 & 33 & 9 & 85.8 & 1.48 & 0.65 & 30 & 3 & 96.7 & 0.32 & 0.15 & 44 & 6 & 97.7 & 1.27 & 0.68 \\
\hline JL-U-S & 15 & 2.60 & 0.92 & 25 & 4 & 96.0 & 0.90 & 0.53 & 29 & 3 & 93.1 & 0.20 & 0.08 & 29 & 5 & 97.4 & 1.00 & 0.53 \\
\hline JL-L-S & 16 & 2.68 & 0.93 & 50 & 3 & 100.0 & 0.83 & 0.54 & 33 & 3 & 100.0 & 0.48 & 0.24 & 38 & 5 & 97.4 & 0.85 & 0.40 \\
\hline BL-U-S & 14 & 2.53 & 0.91 & 34 & 3 & 100.0 & 0.58 & 0.39 & 26 & 2 & 100.0 & 0.17 & 0.08 & 37 & 5 & 97.3 & 1.42 & 0.73 \\
\hline BL-L-S & 15 & 2.60 & 0.92 & 44 & 3 & 100.0 & 0.73 & 0.41 & 40 & 4 & 97.5 & 0.60 & 0.28 & 44 & 7 & 95.5 & 1.48 & 0.70 \\
\hline Di-U-S & 8 & 1.97 & 0.85 & 33 & 2 & 100.0 & 0.55 & 0.37 & 30 & 3 & 93.3 & 0.20 & 0.08 & 27 & 6 & 88.9 & 1.45 & 0.69 \\
\hline Di-L-S & 9 & 2.06 & 0.85 & 36 & 6 & 97.2 & 1.60 & 0.77 & 33 & 3 & 93.9 & 0.20 & 0.08 & 30 & 10 & 86.7 & 2.05 & 0.85 \\
\hline
\end{tabular}


609 Figure S1 DGGE profile of anammox bacterial 16S rRNA gene from Laizhou Bay tidal flats in winter (A) and in

610 summer (B). Position of bands was highlighted with the numbered arrows

612 Figure S2 A neighbor-joining tree showing the phylogenetic positions of ammonia-oxidizing bacterial amoA gene from tidal flats of Laizhou Bay. Bootstrap values no less than $50 \%$ are shown at the nodes. The scale bar indicates 0.1 nucleotide substitution per site. The $\gamma$-proteobacterial Nitrosococcus oceani is used as the outgroup

Figure S3 A neighbor-joining phylogenetic tree showing the affiliation of ammonia-oxidizing archaeal amoA genes obtained from tidal flats of Laizhou Bay. Bootstrap values no less than 50\% are shown at the nodes. The scale bar indicates 0.05 nucleotide substitution per site. The ammonia-oxidizing bacteria (JX465202) from tidal flats of Laizhou Bay is used as the outgroup

Figure S4 Phylogenetic analysis of denitrifying nosZ gene obtained from Laizhou Bay estuarine tidal flats. Bootstrap values no less than $50 \%$ were shown at the nodes. The scale bar indicates 0.1 nucleotide substitution per site. The $\delta$-proteobacterial Anaeromyxobacter dehalogenans is used as the outgroup

Figure S5 Phylogenetic relationships of anammox bacterial 16S rRNA genes as determined by neighbor-joining method. Bootstrap values no less than $50 \%$ were shown at the nodes. The scale bar indicates 0.1 nucleotide substitution per site. 
630 Figure

631 S1
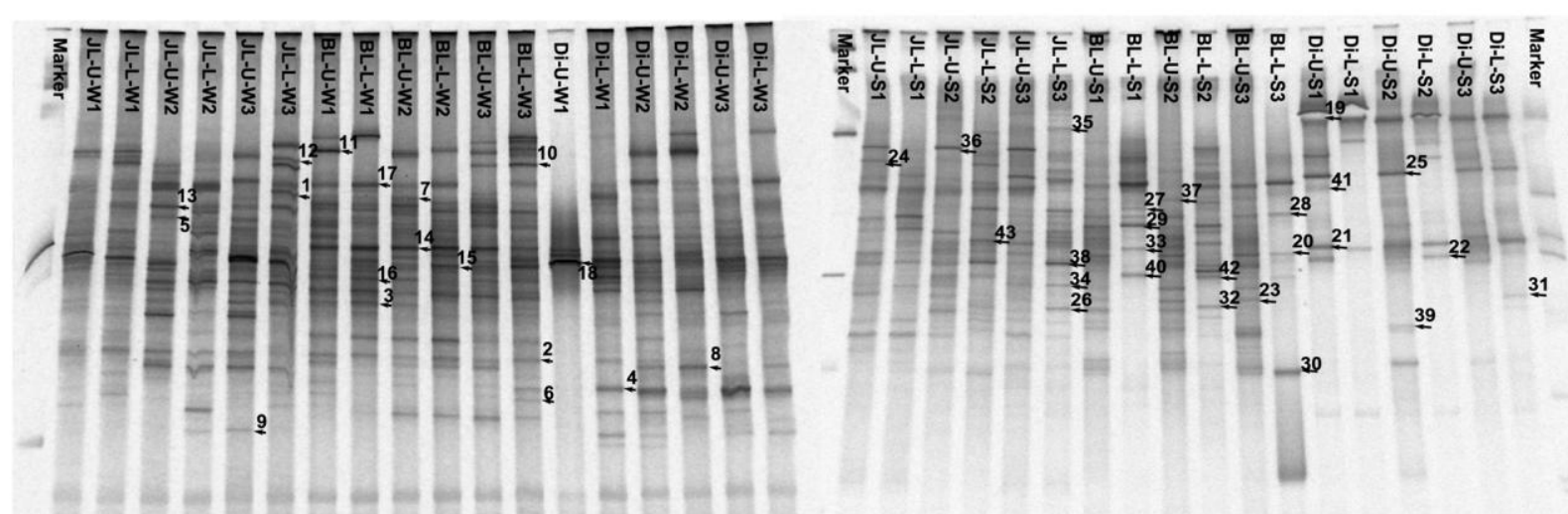

A

B

632

633 
Figure S2

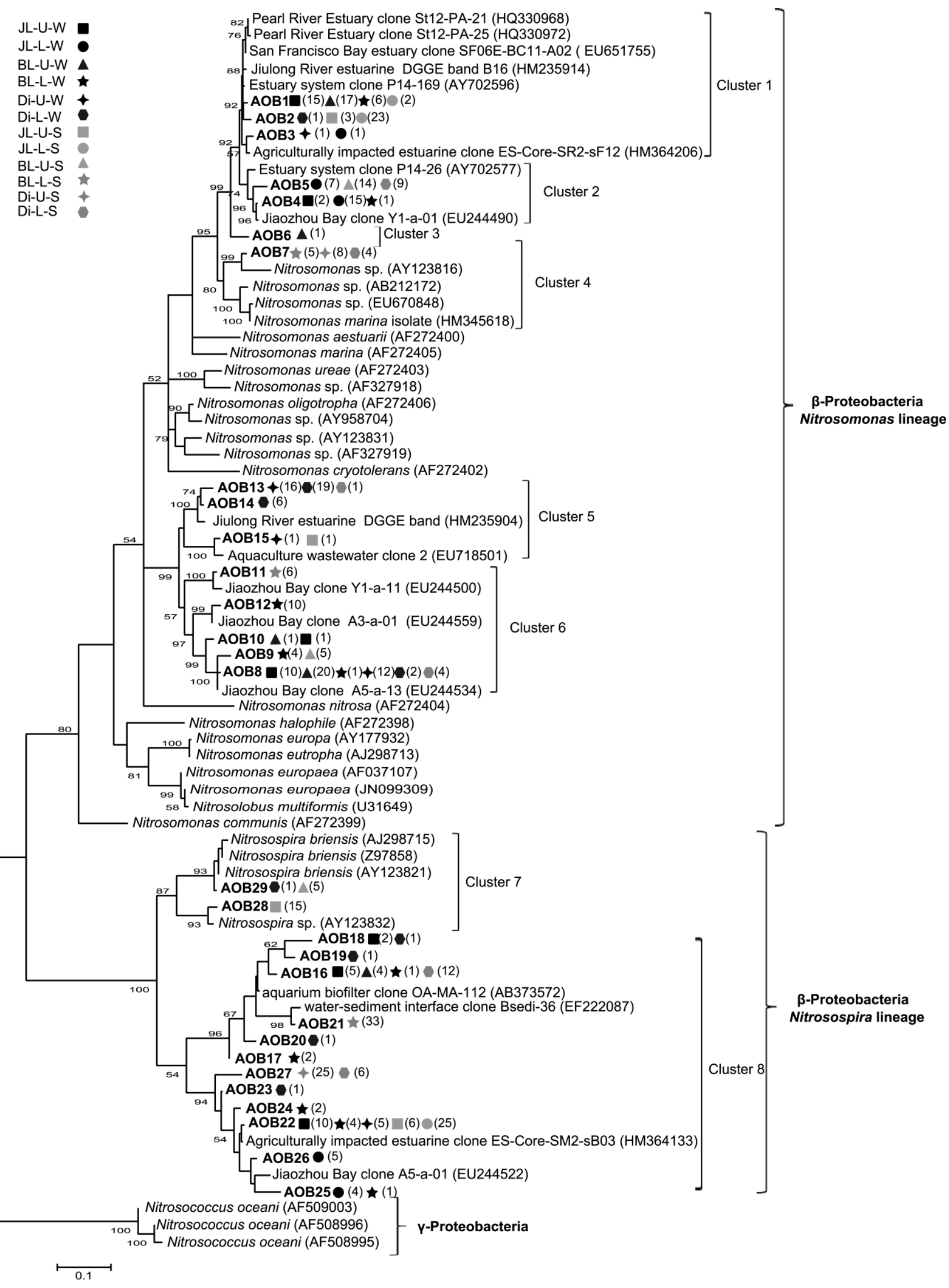




JL-U-W
JL-L-W
BL-U-W
BL-L-W
D-U-W
D-L-W
JL-U-S
JL-L-S
BL-U-S
BL-L-S
D-U-S
D-L-S

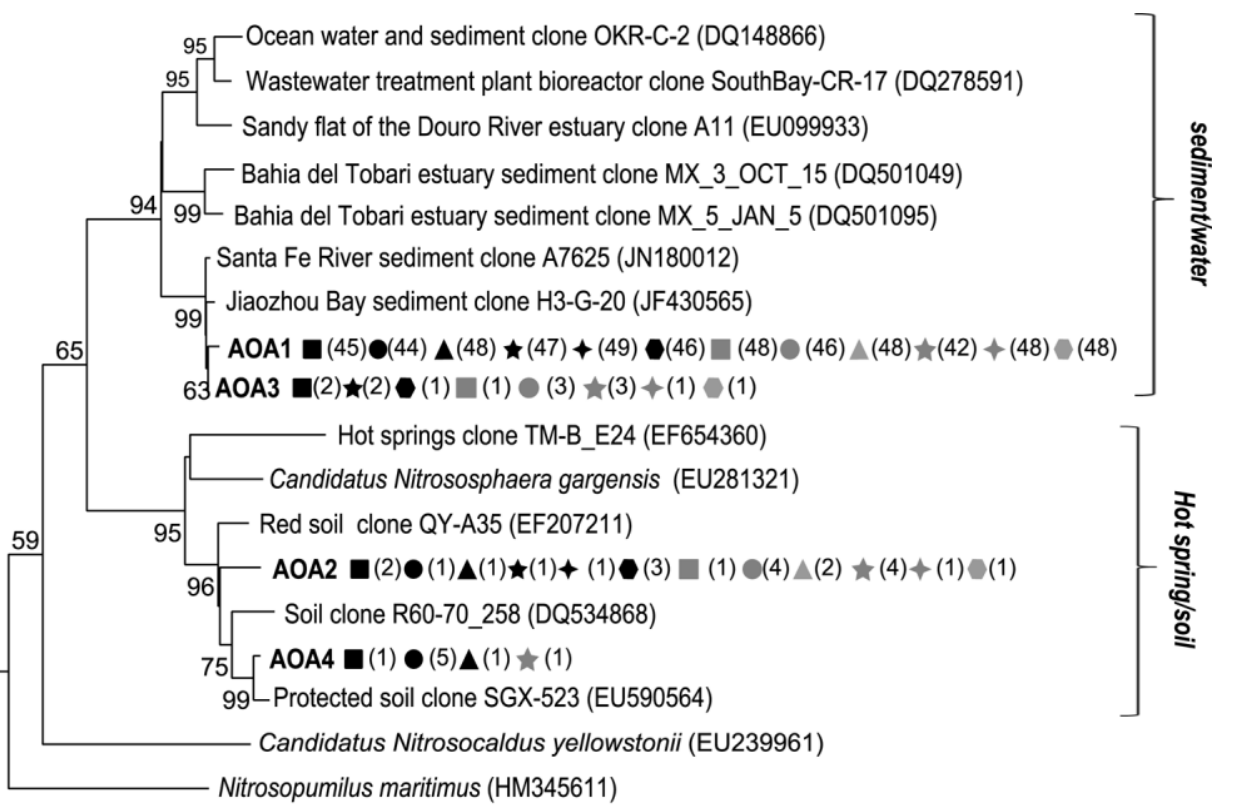




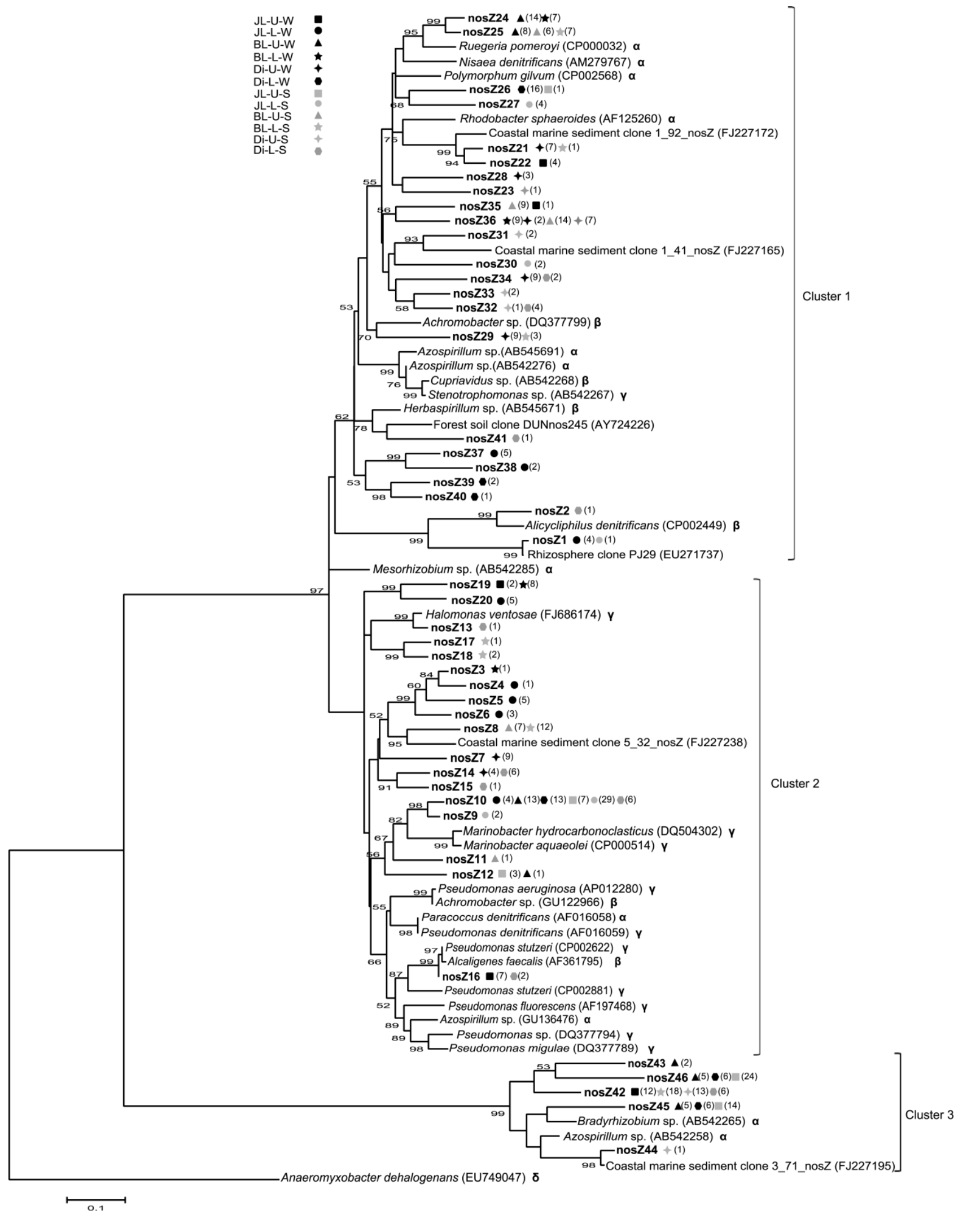




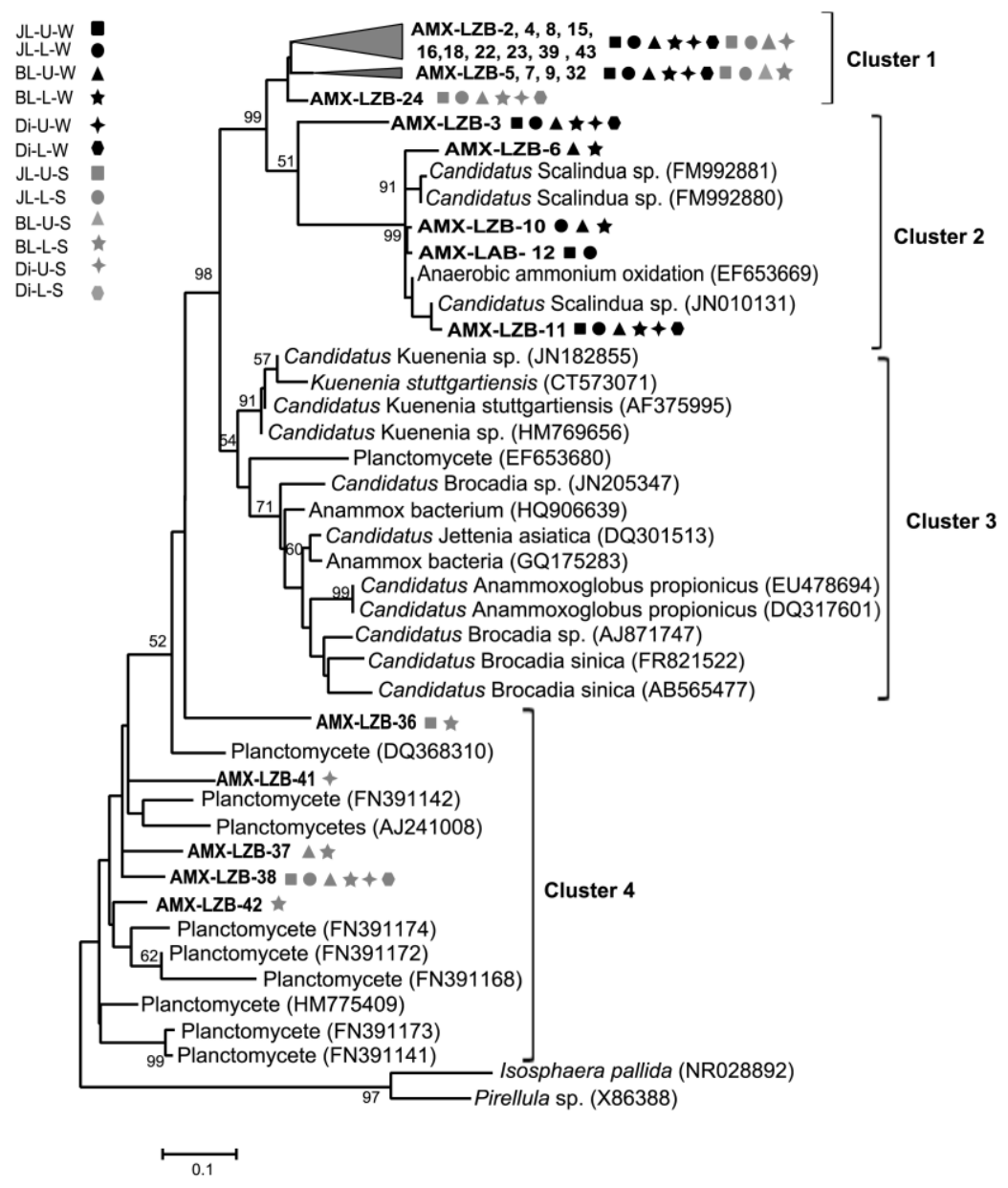

